\title{
Forensic science
} expertise for international criminal proceedings: an old problem, a new context and a pragmatic resolution

\author{
By Melanie Klinkner \\ MA Albert-Ludwigs-Universität Freiburg, PhD candidate, \\ Bournemouth University
}

Abstract Expert witness testimony provides an important source of information for international criminal proceedings, and forensic science expertise from mass graves is no exception: findings from exhumations and examinations have featured in the ad hoc tribunals' trials and judgments. Whilst the issues surrounding the law-science relationship have been explored within the realm of national legal systems, the mixed system adopted by these tribunals presents an established discussion with a new context. Using forensic archaeology as an example, this article explores some theoretical underpinnings and practical realities surrounding the use of forensic science during international criminal investigations into mass graves before looking at how Trial Chambers aim to establish the relevance and credibility of forensic science evidence. As little guidance regarding admissibility of expert evidence is provided, it is through the case-specific legal process of cross-examination and presentation of

* The author wishes to thank the Editor, Paul Roberts, for the extensive and useful comments made on drafts of this article as well as Bournemouth University and The Harold Hyam Wingate Foundation for financially supporting this research. 
counter-expertise that methodological issues are resolved. This, together with reliance on normative principles, is the pragmatic approach adopted to discern reliability of expert opinion.

Keywords Expert witness testimony; Forensic science; International criminal proceedings; Law-science relationship; Mass graves

ince the commencement of the trials at the International Criminal Tribunal for the Former Yugoslavia (ICTY), the judges have heard numerous testimonies from expert witnesses. Expert witness testimonies during international criminal trials have been paramount, due to the complexity of cases adjudicated. Often, in order to establish whether the accused is guilty, the context, including political, military and historical information, needs to be explored. Thus, expert witnesses are asked to provide clarification on elements relevant to the trial that require specialist knowledge. 'They are normally allowed to testify on issues about which the judges themselves, based on their personal knowledge and experience, cannot be expected to reach an opinion alone. ${ }^{11}$ Introducing expert testimony can increase the complexity surrounding a case, yet simultaneously help reduce that complexity to a level manageable by judicial fact-finders at the ICTY.

Expert witnesses are also called to testify about the particular crimes that are alleged in the proceedings. Forensic science investigations into mass graves have been a major activity within the ICTY's Office of the Prosecutor, providing vital evidence from the crime scene in order to facilitate successful prosecution. Expert evidence regarding the exhumation of mass graves has been important for a number of trials, specifically those relating to the Srebrenica crimes in Bosnia and Herzegovina. $^{2}$ Whilst forensic science evidence from crime scenes does not attempt to explain why certain crimes were committed, it can give indications as to what happened and how. It attempts to answer these empirical questions through well-designed empirical studies and inquiries.

To date, little attention has been paid to how international law interfaces with expert witnesses and forensic science experts in particular. ${ }^{3}$ It is anticipated that

1 W. A. Schabas, The UN International Criminal Tribunals: The Former Yugoslavia, Rwanda and Sierra Leone (Cambridge University Press: Cambridge, 2006) 480.

2 See e.g. Krstić (Case No. IT-98-33); Milošević (Case No. IT-02-54); and Popović et al. (Case No. IT-05-88).

3 This is different for domestic settings, where numerous publications examine the law-science relationship. See e.g. M. Freeman and H. Reece (eds), Science in Court (Ashgate: Aldershot, 1998); S. Jasanoff, 'Just Evidence: The Limits of Science in the Legal Process' (2006) 34 Journal of Law, Medicine \& Ethics 328-41; S. Jasanoff, 'Law's Knowledge: Science for Justice in Legal Settings' (2005) 95 American Journal of Public Health 49-58; D. L. Faigman, D. H. Kaye, M. J. Saks and J. Sanders (eds), Modern Scientific Evidence. The Law and Science of Expert Testimony (West Publishing Co.: St Paul, Minnesota, 2002); and M. Redmayne, Expert Evidence and Criminal Justice (Oxford University Press: Oxford, 2001). 
the use of expert witnesses will continue to be imperative for the future administration of international justice because of the complexity of trying perpetrators accused of genocide, crimes against humanity, war crimes and/or the crime of aggression. ${ }^{4}$ The potential value of forensic science for international justice is all the greater to the extent that some transitional justice scholars believe that one rationale for, and a function of, justice is to create an accurate historical record. ${ }^{5}$ Relying on expert knowledge and the opinions and facts it provides is commonly accepted to be a good strategy for achieving justice, as long as the expertise is impartial and truthful. This is particularly the case for experts presenting their scientific findings and explanations; for science-to many-offers better explanations than non-science. ${ }^{6}$ However, increasing dependence on expertise also introduces new uncertainties, which are inherent to the scientific discipline, to the relationship between science and law. ${ }^{7}$

Over the centuries, philosophers of science have tried to answer questions about what makes scientific findings truthful and to formulate standards that would help identify good scientific explanations. They have considered whether scientific pronouncements ought to be causal, unified, nomological, statistical, deductive, inductive or any combination of these. ${ }^{8}$ Given that philosophers wrestle with such questions, how are ICTY Trial Chamber judges, with their judicial expertise and limited time for deliberation, to determine what makes scientific results valid and reliable, truthful and credible? The issue of 'science v.

4 These crimes are within the jurisdiction of the International Criminal Court: Rome Statute of the International Criminal Court 1998, Art. 5; the ICTY is to prosecute grave breaches of the Geneva Conventions of 1949, violations of the laws or customs of war, genocide and crimes against humanity within the ICTY Statute's jurisdictional limits: Statute of the International Criminal Tribunal for the Former Yugoslavia 1993, Arts 2-5, as amended.

5 Scharf and Williams, for example, believe that the creation of a historical record is one element of the justice process needed to create peaceful societies after war. 'These include establishing individual responsibility and denying collective guilt, dismantling and discrediting institutions and leaders responsible for the commission of atrocities, establishing an accurate historical record, providing victim catharsis, and promoting deterrence': M. P. Scharf and P. R. Williams, 'The Functions of Justice and Anti-Justice in the Peace-Building Process' (2003) 35 Case Western Reserve Journal of International Law 170. This contrasts with Hannah Arendt's argument that the first and foremost purpose of a trial 'is to render justice, and nothing else; even the noblest of ulterior purposes ... can only detract from the law's main business: to weigh the charges brought against the accused, to render judgment, and to mete out due punishment': H. Arendt, Eichmann in Jerusalem. A Report on the Banality of Evil (Penguin: London, 1994 [1963]) 253.

6 See A. Rosenberg, Philosophy of Science: A Contemporary Introduction (Routledge: Florence (USA), 2000).

7 According to Willmore, introducing scientific evidence based on novel, and potentially unreliable, techniques brings uncertainties to the legal process; it raises questions as to how evidence should be evaluated: C. Willmore, 'Codes of Practice: Communicating between Science and Law' in Freeman and Reece, above n. 3 at 37.

8 See Rosenberg, above n. 6. 
non-science' is further complicated by the recognition that 'despite its obvious value, forensic science has not always merited the term "science". 9 Forensic science is not a discipline as such, but rather the application of a range of sciences, alongside techniques and skills that do not qualify as science, to legal proceedings. Furthermore, whilst mass grave exhumations had been conducted for humanitarian purposes, the investigation of mass graves for prosecution purposes has been pioneered by the ICTY, posing new challenges for the forensic scientists involved.

The ICTY's Rules of Procedure and Evidence (RPE) provide little guidance as to the admissibility of expert evidence, or scientific evidence for that matter, be it in the form of a report or through giving testimony in court. ${ }^{10}$ This poses an important question: by what criteria, whether epistemic, logical or normative, do ICTY judges decide which scientific account to accept? Having highlighted the theoretical underpinnings and some practical realities of forensic science investigations under the auspices of the ICTY, this article considers how Trial Chambers approach the admissibility and evaluation of one particular genre of scientific evidence, the forensic sciences involved during mass grave investigations. Adopting an interdisciplinary approach, the discussion draws on ICTY trial transcripts and semi-structured in-depth interviews conducted by the author with forensic experts, lawyers, investigators and judges involved at the ICTY which are part of a wider study into the 'forensic science-international criminal law' interface. ${ }^{11}$

\section{Two views of science}

What warrants the scientific adequacy of an explanation and what justifies science's perceived empirical success and subsequent claims to objective knowledge? The traditional answer given by philosophers of science is that if science relies on the 'right' methods, methods that are firmly rooted in logic and

9 P. C. Giannelli, 'Forensic Science' (2006) 33 Journal of Law, Medicine \& Ethics 310.

10 Popović et al. (Case No. IT-05-88-T) Decision on Defence Rule 94 bis Notice regarding Prosecution Expert Witness Richard Butler, 19 September 2007, para. 22.

11 For the ICTY case study a total of 18 individuals (seven forensic experts, five current or former ICTY lawyers, four current or former ICTY investigators and two current or former ICTY judges) were interviewed; individuals were selected based on network sampling and due to their first-hand experience of forensic science during international criminal investigations and proceedings (judgment sampling). The semi-structured in-depth interviews lasted on average 65 minutes and covered the role, value and use of forensic science during international criminal investigations and proceedings. All interviews were transcribed verbatim and with the use of the qualitative software package QSR NVivo coded and analysed. To guarantee the anonymity of participants, quotations that illustrate the interviewees' views will remain unattributed with descriptive pseudonyms indicating their profession. 
valid epistemic claims, its results should be sound. ${ }^{12}$ The scientific method is concerned with 'the problem of how to observe an empirical problem in a way that will allow one to draw inferences about that phenomenon'. ${ }^{13}$ Such methods encompass investigative techniques which usually aim to collect empirical measurable evidence, through observation, experimentation and the formulation and testing of hypotheses. The process can be summarised in five steps: ${ }^{14}$

1. the observation of the explanandum or the phenomenon that needs clarification;

2. the development of a possible explanans or theory about the explanandum;

3. the formulation of hypotheses that are logically derived from the theory;

4. the design of studies to test the hypotheses, which might be capable of disconfirming a hypothesis and the correlating theory; and

5. the formulation of a better theory or more credible explanans whose hypotheses have not been falsified.

The forensic science disciplines employed throughout international criminal investigations into mass graves are, at the site level, predominantly forensic archaeology and anthropology, and, in the mortuary, forensic pathology and anthropology. ${ }^{15}$ However, before exploring how the prefix forensic impacts upon science, it is illuminating to consider how archaeology, ${ }^{16}$ as one of the key disciplines involved in mass grave investigations, defines itself as a science.

In the 1960 s attempts were made from within archaeology to render the discipline more scientific and rigorous. ${ }^{17}$ This development was inspired by the emergence of logical positivism in the 1920s and 1930s which attempted to free science from its superfluous metaphysical baggage and ground it firmly in logic. ${ }^{18}$ Archaeology

12 See Rosenberg, above n. 6.

13 D. L. Faigman, D. H. Kaye, M. J. Saks and J. Sanders, 'Scientific Method: The Logic of Drawing Inferences from Empirical Evidence' in Faigman et al., above n. 3 at 120.

14 The five steps are a shortened and modified version of the passage on theory-development outlined by Faigman et al., ibid. at 125.

15 This article will not consider other disciplines, despite radiographers, odontologists and support staff being involved in forensic investigations. It is only the forensic archaeologist, anthropologist and pathologist (plus one odontologist) who have given testimony regarding forensic exhumations and examinations in The Hague.

16 The author treats archaeology as a stand-alone discipline and not, as commonly done in North America, as a sub-discipline of anthropology.

17 Kelley and Hanen refer to this as the emergence of New Archaeology: J. H. Kelley and M. P. Hanen, Archaeology and the Methodology of Science (University of New Mexico Press: Albuquerque, 1988) 12. 18 Ibid. 
turned to the philosophy of science for guidance as to the method, explanation and confirmation deemed necessary to put archaeology on a sound scientific footing. The debate focused upon inductivism and deductivism as methods of discovery and on deduction (especially Hempel's deductive-nomological model ${ }^{19}$ ) and induction as tools to justify conclusions drawn from data. ${ }^{20}$ Whilst deductive inferences are deemed true provided the premises are accepted as true, inductive inferences are evaluated according to their contextual strengths and are thus a matter of degree of credibility, rather than certainty. Although inductive arguments do not necessarily produce certainty, they make an important contribution to sciences such as archaeology, for archaeology observes particulars and therefore has to justify its claims through inductively constructed generalisations. Similarly, on a study design level, archaeology's starting point for research is often a single case and is an essentially inductive process.

However, archaeology faced philosophical criticisms that went beyond the familiar debates about its logical reasoning and foundations. Contemporary archaeology, according to Jones, is essentially split into two camps, each with different views as to what the study of archaeology involves: those practising interpretative approaches criticise the positivist stance (and are thus closer to the social sciences), whilst those practising scientific archaeology reject post-positivist views about the world, and thus remain wedded to the realm of natural science. ${ }^{21}$

Post-positivism gained momentum from Kuhn's classic socio-historical study of scientific method and epistemology, The Structure of Scientific Revolutions. ${ }^{22}$ Rosenberg observes that:

[t]he impact of its doctrines within and beyond the philosophy of science is difficult to overstate. Kuhn's doctrine became the lever with which historians, psychologists, sociologists, dissenting philosophers, scientists, politicians, humanists of every strip [sic], sought to undermine the claims of science to objective knowledge, its claims to greater credence than alternative claims about the world. ${ }^{23}$

19 Rosenberg describes Hempel's model with the following statements: ' 1 . The explanation must be a valid deductive argument. 2 . The explanans must contain at least one general law actually needed in the deduction. 3 . The explanans must be empirically testable. 4 . The sentences in the explanans must be true': above n. 6 at 28.

20 See Kelley and Hanen, above n. 17 at 44-51.

21 A. Jones, Archaeological Theory and Scientific Practice (Cambridge University Press: Cambridge, 2002) ch. 1.

22 T. S. Kuhn, The Structure of Scientific Revolutions, 3rd edn (University of Chicago Press: Chicago, 1996 [1962]).

23 Above n. 6 at 148. 
Kuhn challenged the logical empiricist view of the history of science as an account of continuous progress and questioned scientific claims to the disinterested pursuit of the truth. Instead, science was cast as a rather more creative undertaking. ${ }^{24}$ This view of science tends to be favoured by those archaeologists concerned with interpreting culture. Owing to the nature of archaeology, which is concerned with the recovery, interpretation and documentation of human culture, the discipline continues to wrestle with uniting the relativistic post-positivist approaches and those preferring the logical and methodological rigour of scientific inquiry and its perceived reproducibility. ${ }^{25}$ We must now address the question: how does forensic archaeology operate under the wider umbrella of the forensic sciences?

\section{Forensic science}

Forensic science is employed in order to investigate cases or questions that are of interest to the legal system and to help solve legal disputes. Within the framework of international criminal proceedings, forensic science is predominantly concerned with helping to establish the actus reus of an atrocity crime, rather than the mens rea of the alleged perpetrator. The fundamental tools of conducting forensic investigations are 'observation and interpretation of physical evidence'. ${ }^{26}$ According to Kiely, the bases of forensic scientific method are:

1. recognition and understanding of what information and evidence could be present at the crime scene;

2. collection procedures during which the scientists collect and record the evidence;

3. the testing phase when the evidence is examined and tested according to current, adequate testing standards; and

4. meeting the evidential requirements of the trial. ${ }^{27}$

How does this model translate into practice? Taking the example of a mass grave investigation and the work of the forensic archaeologist, the mass grave becomes the phenomenon in need of scientific explanation. In formal terms, it is the explanandum. From the explanandum, archaeology works towards the explanans, the posited or hypothesised explanation of the phenomenon. This is essentially an

24 Above n. 22.

25 See Jones, above n. 21 at 20.

26 W. G. Eckert, 'Introduction to the Forensic Sciences' in W. G. Eckert (ed.), Introduction to Forensic Sciences (CRC Press: Boca Raton, 1997) 1. The underlying assumption of forensic science is known as Locard's principle which states that every contact leaves a trace: see Redmayne, above n. 3.

27 T. F. Kiely, Forensic Evidence: Science and the Criminal Law, 2nd edn (Taylor and Francis: Boca Raton, 2006) 53. 
etiological task during which archaeology employs observation and collection techniques (such as geophysical surveying) to establish causation. The mass grave is viewed as a crime scene and the initial theory might be related to when it was created, what events it is connected to, and whose bodies it may be concealing (for example, that it was created in the summer of 1995 to bury victims of mass execution and contains Bosnian Muslim men). This initial theory will then influence the methods and techniques employed to undertake the exhumation, always ensuring that the chain of custody is documented and preserved. Testing as such is very limited, due to the invasive nature of archaeological techniques and the fact that exhumations can only be conducted once. Depending on the findings, the scientist revisits the explanans in order to refine the account of how and when the grave was created, whether the original grave had been disturbed, and the number of entire corpses or body parts it contains. ${ }^{28}$

The practice of the forensic archaeologist better fits the model of the empiricist scientist rather than post-positivism. Practitioners are recording physical objects which they believe are caused by past events. These objects are interpreted as representations of past events and processes. The forensic scientist's work has little to do with anthropogenic or cultural processes, but rather with causes and scientific laws. How does this bear on the validity and reliability of the archaeologist's conclusions, the forensic explanans? The explanans is a 'relation between theory, fact and context'. ${ }^{29}$ Forensic science is the application of science-as opposed to pure science-to a specific context with the aim of answering a specific question. In the context of mass graves, the question may be: what information does the mass grave contain? Based on the condition of the site and the additional information it yields, a causal account explaining what probably occurred at a mass grave can be progressively refined to form the final explanans. Of course, there is always the possibility of human error and lack of experience or training which could discredit the explanans or render it false. ${ }^{30}$ Moreover, the explanandum and its related evidence might be consistent with alternative causal hypotheses. Furthermore, as Redmayne points out, '[m]uch writing on forensic science evidence stresses the role of interpretation in the process of drawing conclusions

28 See e.g. R. Wright, 'Report on Excavations and Exhumations at the Glogova 1 Mass Grave in 2000' (ICTY Report: The Hague, 2001).

29 See Kelley and Hanen, above n. 17 at 219.

30 Forensic Anthropologist and ICTY expert witness Dr William Haglund acknowledges that depending on the condition of the grave and the human remains within it, errors might occur regarding the total number of individuals recovered, especially during the numbering, removal and storage stages of the forensic investigation. He also points out that the margin of error increases the higher the number of staff involved throughout an investigation: W. D. Haglund, 'Recent Mass Graves: An Introduction' in W. D. Haglund and M. H. Sorg (eds), Advances in Forensic Taphonomy: Method, Theory and Archaeological Perspectives (CRC Press: Boca Raton, 2002) 256-7. 
from the examination of physical evidence'. ${ }^{31}$ Despite the expectation that the basis of any interpretation should be accessible to the scientific community as a whole $^{32}$ interpretation bears the connotation of subjectivity, individual discretion and probability, rather than objective certainty. This potential 'under-determination' of the explanans reopens the door for the debate about scientific certainties and post-positivist constructivist claims.

Forensic scientists have tried to address the challenges of alternative causes and lingering uncertainty, either by conducting more discriminating experiments and inquiries to produce more definitive results, or by employing formulae such as Bayes' theorem to model alternative hypotheses and calculate 'their convergence on the most reasonable probability values'. ${ }^{33}$ In domestic criminal investigations, forensic science typically involves recovering and testing trace evidence in a laboratory to identify the perpetrator and link him or her to the crime under investigation. Statistical models may be available and feasible procedures in place to ensure that all material evidence is taken into account and all plausible hypotheses considered. Such procedures and statistical models cannot easily be extrapolated to mass grave investigations, however, in which cause and manner of death or determination of the sex of the deceased are primarily at issue. These questions are settled, not by the application of statistical models or base-rates, but rather through accumulating physical evidence. To mitigate the impact of subjectivity, bias and differing levels of professional experience, forensic archaeologists, anthropologists and pathologists rely on operating procedures, thorough recording protocols, ${ }^{34}$ and consultation with colleagues to promote accuracy. Achieving consensus in the interpretation of findings is, as one study interviewee explained, the product of 'very strong teamwork' ${ }^{35}$ At the ICTY forensic procedures and protocols were created, adopted and amended in

31 See Redmayne, above n. 3 at 30. As anthropologist Byers notes in his textbook, '[o]ne of the most common problems faced by forensic anthropologists [and shared by the forensic archaeologists and pathologists respectively] is how to make a single determination from ambiguous data': S. Byers, Introduction to Forensic Anthropology, 3rd edn (Pearson: Boston, 2008) 16.

32 P. Cobb, 'Forensic Science' in P. White (ed.), Crime Scene to Court. The Essentials of Forensic Science (Royal Society of Chemistry: Cambridge, 1998) 9.

33 See Rosenberg, above n. 6 at 132. For a detailed explanation of probability models and the Bayesian turn within the forensic sciences, see M. Redmayne, 'Bayesianism and Proof in Freeman and Reece (eds), above n. 3 at 61-81.

34 Given that reproducibility within a mass grave is hardly possible, the recording and documentation element becomes an important source of information and evidence for the court, as expert reports and photographs can be examined by other experts not involved in the original forensic investigation. Photographs in particular often function as a quality control.

35 Forensic expert \# 3, personal interview, 30 May 2007. 
agreement with the leading scientific expert, prosecution lawyer and investigator to satisfy both scientific and investigative requirements. ${ }^{36}$

\section{Case construction and forensic truth}

Methodological and procedural protocols in forensic science, no matter how rigorously applied, are incapable of silencing post-positivist critics. Even if scientific method in itself were unimpeachable, there are two further contextual variables capable of introducing distorting influences. First, we must consider how, in general terms, the wider dictates and demands of criminal investigation affect the conduct of scientific inquiries and their results. Secondly, we must take into account how criminal proceedings affect the behaviour of individual forensic scientists in particular cases.

The general idea that cases are 'constructed' by police and the prosecution is well-known. ${ }^{37}$ It is important to explore whether forensic science results are equally subject to construction, since this necessarily conditions evidentiary relevance and impacts upon the quality of decision-making in court. The ICTY adopts an essentially adversarial model of investigation whereby 'the prosecutor, a party to the proceedings, investigates, collects evidence and decides what matters should be presented for indictment'. ${ }^{38}$ Boas argues that its adversarial antecedents inevitably detract from the reliability of the evidence adduced before the ICTY. Information produced in this way is less trustworthy, he suggests, than the evidential product of investigations conducted under the auspices of an independent judicial officer, as is the case in the civilian legal systems of Continental Europe. ${ }^{39}$

The constructivist literature on science and law expresses the belief that scientific knowledge is socially constructed. In the first instance, the overall context of the criminal investigation, as dictated by prosecutorial strategy and the exigencies of securing access to relevant sites (which is far from a trivial consideration in war zones or politically unstable post-conflict regions), determines which potential crime scenes will be investigated. Particular mass graves are selected for their

36 Forensic expert \# 6, telephone interview, 16 May 2007; ICTY lawyer \# 2, personal interview, 10 December 2007; and ICTY investigator \# 2, personal interview, 12 December 2007.

37 See e.g. W. L. Bennett and M. S. Feldman, Reconstructing Reality in the Courtroom (Tavistock Publications: London, 1981) and Redmayne, above n. 3.

38 G. Boas, 'A Code of Evidence and Procedure for International Criminal Law? The Rules of the ICTY' in G. Boas and W. A. Schabas (eds), International Criminal Law Developments in the Case Law of the ICTY (Martinus Nijhoff: Leiden, 2003) 26.

39 Ibid. at 32. 
expected relevance to the case. ${ }^{40}$ The scope of the inquiry is further narrowed down by operational and institutional constraints on available resources, equipment, health and safety considerations, budget and time limits. In addition, as Jasanoff points out, it may be that the specialised scientific expertise required for the purposes of litigation is 'unavailable until the legal process itself creates the incentives for generating it'. ${ }^{41}$ Thus, proceedings at the ICTY pioneered the use of international multi-disciplinary teams for investigating war crimes, genocide and crimes against humanity as opposed to investigations for primarily humanitarian purposes. ICTY exhumations of mass graves in Bosnia and Herzegovina and Croatia started in 1996 and ended in 2001. Relevant expertise was accumulated and refined over time. Those called as experts before the Tribunal initially had little prior experience regarding mass grave exhumations and examinations on such a large scale before embarking on forensic missions for the ICTY. Novel scientific expertise developed in response to the bespoke requirements of legal process extends beyond the pre-existing boundaries of scientific consensus, which compounds the courts' difficulties in assessing the validity and reliability of forensic science evidence.

Much of the constructivist law and science literature focuses on the individual scientist who becomes an expert witness. ${ }^{42}$ It has been suggested that 'scientists are not disintegrated agents but rather are immersed in a web of relations that play an important role in determining the character of truths that emerge from their interaction'. ${ }^{43}$ In conducting their investigations and presenting their results, experts are constrained to try to conform to the socially constructed expectations of their discipline. Worse, given the contextual pressures of criminal investigations, experts risk losing their impartiality and objectivity. ${ }^{44}$ Yet it is impossible to insulate forensic scientists from the background information they need to undertake their work. As one interview respondent explained, forensic scientists 'are not on a fishing exercise'. ${ }^{45}$ Another expounded:

40 For more comprehensive descriptions of crime-scene selection, see M. Skinner and J. Sterenberg, 'Turf Wars: Authority and Responsibility for the Investigation of Mass Graves' (2005) 151 Forensic Science International 221-32; and M. Klinkner, 'Proving Genocide? Forensic Expertise and the ICTY' (2008) 6 Journal of International Criminal Justice 447-66.

41 See Jasanoff (2005), above n. 3 at 54.

42 See G. Edmond, 'Science, Law and Narrative' (1999) 23 Southern Illinois University Law Journal 555-83; N. M. Browne, T. J. Keeley and W. J. Hiers, 'The Epistemological Role of Expert Witnesses and Toxic Torts' (1998) 36 American Business Law Journal 1-72; and S. Jasanoff (2006), above n. 3.

43 See Browne et al., above n. 42 at 50.

44 Redmayne goes so far as to suggest that '[b]ias appears to be a universal tendency in forensic science': above n. 3 at 13.

45 Forensic expert \# 6, telephone interview, 16 May 2007. 
They could be the best experts on God's earth but at the same time if they don't really know what they are looking for, besides the obvious, I mean, they'd find bodies and they'll find shell casings, but small things ... they would miss. ${ }^{46}$

Roberts and Willmore suggest that adversarial scrutiny and counter-expertise are the best means available to offset the potentially corrupting influences of background information and partisan instructions. ${ }^{47}$ However, concerns regarding the forensic expert's independence and objectivity remain. They are rooted in cognitive science, as Redmayne explains:

We tend to look for confirming, rather than disconfirming, evidence; we may judge evidence of better quality if it agrees with our theory, of worse quality if it does not; and our beliefs can persevere even after being discredited. It also appears that extraneous information supporting a hypothesis will affect our judgement of that hypothesis, and of the evidence for it, even when we know we should not take the extraneous information into account. ${ }^{48}$

Scholars in the common law tradition have portrayed the law-science relationship as 'an uncomfortable alliance', ${ }^{49}$ and expressed the fear that the legal system might not have the right tools to evaluate scientific information. ${ }^{50}$ Edmond elaborates:

Because the various sciences maintain different approaches, theories, criteria, canons of practice, metaphysics, levels of relevance, levels of abstraction and so on, it would be highly naive to suggest that we could expect some basic or universal criteria which could be applied consistently to determine 'reliability'. ${ }^{51}$

Despite fundamental problems with assessing reliability, however, there are also a number of similarities between the disciplines, especially when focusing on

46 ICTY investigator \# 1, telephone interview, 30 July 2007.

47 P. Roberts and C. Willmore, The Role of Forensic Science Evidence in Criminal Proceedings, Royal Commission on Criminal Justice Research Study No. 11 (HMSO: London, 1993) 36.

48 See Redmayne, above n. 3 at 15 (footnotes omitted).

49 G. Edmond, 'Science in Court: Negotiating the Meaning of a "Scientific" Experiment during a Murder Trial and Some Limits to Legal Deconstruction for the Public Understanding of Law and Science' (1998) 20 Sydney Law Review 361.

50 See Willmore, above n. 7.

51 G. Edmond, 'Judicial Representations of Scientific Evidence' (2000) 63 Modern Law Review 251. 
forensic science. ${ }^{52}$ Both the legal system and forensic science aim to produce knowledge, albeit with a functional difference: the legal system finds facts as the basis for justice, whilst forensic science produces knowledge for the sole purpose of assisting the court in its fact-finding task. Both are limited by the context of the case at hand, both are bound by legal procedures or scientific protocols, both belong to professional communities and subscribe to a professional ethos. There are also notable structural parallels between their respective approaches to generating accurate knowledge: the law relies on courtroom testimony, whereas empirical science is built upon recorded observations; testing the evidence through cross-examination in court in some ways resembles scientific techniques of hypothesis testing and falsification. As Willmore points out, however, one major difference remains: whilst the sciences are familiar and comfortable with uncertainties and undetermined aspects of enquiries and evidence, 'legal systems demonstrate discomfort with uncertainty'. ${ }^{53}$ The law operates as though there is one correct explanation to be discovered. Yet, the level of proof required for judicial verdicts at the ICTY is 'proof beyond reasonable doubt', which is an inherently probabilistic concept and thus not dissimilar to the sciences operating with probability intervals.

\section{A new context: forensic science at the ICTY}

Rule 89 of the ICTY's Rules of Procedure and Evidence outlines the general provisions regulating evidentiary matters before the Tribunal:

(A) A Chamber shall apply the rules of evidence set forth in this Section, and

(B) In cases not otherwise provided for in this Section, a Chamber shall apply the rules of evidence which will best favour a fair determination of the matter before it and are consonant with the spirit of the [ICTY] Statute and the general principles of law.

(C) A Chamber may admit any relevant evidence which it deems to have probative value.

(D) A Chamber may exclude evidence if its probative value is substantially outweighed by the need to ensure a fair trial.

(E) A Chamber may request verification and authenticity of evidence obtained out of court.

52 In the subsequent passage I follow partly an exposition of Jasanoff regarding the US legal system and the use of science for trial purposes, adapting the arguments to the international criminal law context and the use of forensic science: see Jasanoff (2005), above n. 3 at 50-3.

53 Above n. 7 at 40. 
(F) A Chamber may receive the evidence of a witness orally or, where the interests of justice allow, in written form. ${ }^{54}$

The procedural rules regulating proceedings before the ICTY adopt a flexible approach to the admissibility of evidence. Evidence is admissible if it is relevant, of probative value, not to the detriment of a fair trial and not otherwise excluded on the grounds stated in Rules 95 and 96 of the ICTY's RPE, which were drafted by the judges themselves and fine-tuned over time. ${ }^{55}$ These provisions 'do not contain a detailed set of technical rules' ${ }^{56}$ A broadly inclusive approach to the admission of evidence reflects the Tribunal's distinctive blend of adversarial and inquisitorial procedural models.

Although the ICTY has adopted a predominantly adversarial model of trial procedure ${ }^{57}$ its approach to evidence is strongly influenced by the philosophy of 'admit everything, determine weight later', ${ }^{58}$ characteristic of inquisitorial legal systems. In the inquisitorial tradition, all relevant information is collated in a dossier and made available to every party, facilitating a collective truth-finding process' ${ }^{59}$ This contrasts sharply with the partisan approach to truth-finding favoured by common law adversarial legal systems, in which 'admissibility is a crucial part of the pre-trial and trial process, and cases can be won or lost on the basis of success in having evidence ruled admissible or inadmissible' ${ }^{60}$ Notwithstanding these marked differences in procedural philosophy, however, both adversarial and inquisitorial models of adjudication are rooted in the rationalist aspiration to ascertain facts on the basis of evidence, including expert evidence.

Fact-finding at the ICTY is performed by professional judges elected by the UN General Assembly, 'who by virtue of their training and experience are able to consider each piece of evidence which has been admitted and determine its appropriate weight' ${ }^{61}$ Arguments for excluding evidence, including scientific evidence, predicated on the shortcomings of lay jurors therefore do not apply. Even though the ICTY may be inclined to admit scientific evidence, in accordance with its broadly inclusionary approach, it does not follow that that evidence will be

54 ICTY Rules of Procedure and Evidence, Rule 89.

55 ICTY judges are both rule-makers and decision-makers.

56 Delalić et al. (Case No. IT-96-21-T) Decision on the Motion of the Prosecution for the Admissibility of Evidence, 19 January 1998, para. 15.

57 See Schabas, above n. 1 at 453.

58 A. Zahar and G. Sluiter, International Criminal Law. A Critical Introduction (Oxford University Press: Oxford: 2008) 384.

59 Ibid. at 351.

60 See Boas, above n. 38 at 24 .

61 Delalić et al., above n. 56 at para. 20. 
afforded much, if any, weight in the Tribunal's deliberations. Furthermore, initial admissibility rulings may be reversed at later stages in the proceedings, as and when further information relating to the validity or reliability of proffered evidence becomes available. ${ }^{62}$

\section{Expert witness status}

The qualifications of an expert witness and the admissibility of an expert report before the ICTY were recently discussed in Popović. The Trial Chamber defined an 'expert witness' as someone who possesses the relevant specific knowledge, experience or skills to help the Trial Chamber come to a better understanding and a conclusion on a technical issue. ${ }^{63}$ The qualifications of an expert, summarised in the expert's curriculum vitae submitted to the court, authorise the expert-unlike an ordinary witness of fact-to state opinions, inferences and conclusions on matters within the realm of her expertise. ${ }^{64}$ The expert is regarded as an assistant to the Trial Chamber or, in the words of one study interviewee, is called 'to teach the court'. ${ }^{65}$ Objectivity and independence are not regarded as formal prerequisites for a witness to qualify as an expert. ${ }^{66}$ Rather, 'the questions of objectivity, impartiality and independence become relevant to assess the weight to be accorded to that opinion evidence'. ${ }^{67}$ Concerns about independence and objectivity should be addressed during cross-examination. Affiliation with a party does not in itself constitute grounds for disqualification. Indeed, forensic scientists are routinely employed by the Office of the Prosecutor, and without this arrangement little scientific expertise or original physical evidence would be available to the ICTY. One study interviewee explained that the expectation is for 'any professional, qualified person in the scientific field to be independent even though employed by the prosecution'. ${ }^{68}$ Professional qualifications would speak for an expert's good faith.

62 Orić (Case No. IT-03-68-T) Order concerning Guidelines on Evidence and the Conduct of Parties during Trial Proceedings, 21 October 2004, Guideline on Evidence (iv).

63 See Popović et al., above n. 10 at paras. 22-23; see also K. D. Rutledge, “"Spoiling Everything”-but for Whom? Rules of Evidence and International Criminal Proceedings' (2003) 16 Regent University Law Review 177.

64 Popović et al., above n. 10 at para. 23. With regard to the presentation of forensic evidence, not only the scientists themselves, but also the investigators involved in the overall investigation and overseeing the forensic work were called to give a summary of the forensic activities.

65 ICTY lawyer \# 4, personal interview, 1 November 2007.

66 See Popović et al., above n. 10 at para. 26.

67 Ibid.

68 ICTY judge \# 2, personal interview, 3 October 2007. 


\section{Admissibility of expert reports}

Standard practice at the ICTY is to tender and admit expert reports through Rule 94 bis, which provides a timetable for disclosure and other preliminaries. ${ }^{69}$ The opposing party is required to indicate whether it intends to accept the expert witness statement, desires to cross-examine the expert witness, disputes her qualifications or challenges the relevance of the witness statement.

Evidence can be denied admissibility on three grounds. First, according to Rule 95, evidence must be excluded if it has been 'obtained by methods which cast substantial doubt on its reliability'. ${ }^{70}$ Secondly, in line with Rule 89(D), evidence ought to be excluded if it jeopardises the fairness of the trial. Thirdly, evidence may be excluded pursuant to Rule $89(\mathrm{C})$ because it lacks probative value. Of these three grounds for exclusion, Rule 95 has greatest salience for the work of scientific experts, as it directly explores the expert's methods of data collection and whether, in light of the way the scientific inquiry was conducted, its results are reliable. Questions of relevance and probative value are the province of lawyers rather than forensic experts.

Provided that no objection is made by the other side, a scientific report can be admitted into evidence without hearing testimony from the expert, so long as the Trial Chamber is satisfied as to the report's relevance and probative value. ${ }^{71}$ Comments by several interviewees suggest that scientific evidence is often accepted by defence teams, who dispute only its relevance to their client. ${ }^{72}$ In

69 See Blagojević and Jokić (Case No. IT-0260-T) Decision on Prosecution's Motion for Admission of Expert Statements, 7 November 2003, para. 20. Rule 94 bis of the ICTY Rules of Procedure and Evidence states:

(A) The full statement of any expert witness to be called by a party shall be disclosed within the time-limit prescribed by the Trial Chamber to the pre-trial Judge.

(B) Within thirty days of disclosure of the statement of the expert witness, or such other time prescribed by the Trial Chamber or pre-trial Judge, the opposing party shall file a notice indicating whether:

(i) it accepts the expert witness statement; or

(ii) it wishes to cross-examine the expert witness; and

(iii) it challenges the qualifications of the witness as an expert or the relevance of all or parts of the report and, if so, which parts.

(C) If the opposing party accepts the statement of the expert witness, the statement may be admitted into evidence by the Trial Chamber without calling the witness to testify in person.

70 Rule 95 of the ICTY Rules of Procedure and Evidence states: 'No evidence shall be admissible if obtained by methods which cast substantial doubt on its reliability or if its admission is antithetical to, and would seriously damage, the integrity of the proceedings'.

71 See Blagojević and Jokić, above n. 69.

72 For example, ICTY lawyer \# 1, telephone interview, 22 May 2007; ICTY investigator \# 3, personal interview, 3 October 2007; and forensic expert \# 6, telephone interview, 16 May 2007. 
Prosecutor v Popović, the ICTY elaborated on the application of the general requirements of relevance and probative value to expert reports, in terms of:

(1) whether there is transparency in methods and sources used by the expert witness, including the established or assumed facts on which the expert witness relied; (2) whether the report is reliable; and (3) whether the contents of the report falls [sic] within the accepted expertise of the witness. ${ }^{73}$

Qualification as an expert does not automatically guarantee the admissibility of the expert's report. The burden lies on the party tendering the evidence to convince the Tribunal that it satisfies Rule 89(C). In Popović, the evidence in question was opposed and its admissibility to be determined after the expert had undergone cross-examination. ${ }^{74}$

\section{Admissibility of summary reports and transcript testimony}

The ICTY's RPE contain several provisions to facilitate better understanding of scientific reports and expert testimony and to expedite the presentation of this material to the Tribunal.

Rule 92 bis RPE authorises the presentation of summary reports by investigators. These are compilations, derived from multiple sources, which aim to give background evidence of the forensic examinations, thereby contextualising and reducing the complexity of the findings. ${ }^{75}$ Summary reports also save trial time, but they may be challenged as hearsay evidence, thus potentially being of little probative value. ${ }^{76}$ In the Milošević case, for example, where court time was at a premium, ICTY investigator Dean Manning provided summary testimony in relation to the forensic investigations conducted at the Srebrenica crime scenes. ${ }^{77}$ Similarly, Manning's report for the Krstić proceedings on physical evidence recovered from Srebrenica execution points and mass graves was subsequently also found to be 'highly relevant to the case and admissible under Rule 89'

73 See Popović et al., above n. 10 at para. 30 .

74 Ibid.

75 See e.g. D. Manning (ICTY Investigator), 'Srebrenica Investigations. Summary of Forensic Evidence-Execution Points and Mass Graves', ICTY, 16 May 2000, available at <http://www.domovina.net/archive/2000/20000516_manning.pdf>, accessed 18 March 2009.

76 Milošević (Case No. IT-02-54-AR73.2) Decision on Admissibility of Prosecution Investigator's Evidence, 30 September 2002, para. 2 (i)-(ii).

77 Witness Statement by Investigations Team Leader Dean Paul Manning, Prosecutor v Milošević (IT-02-54-T), 24 November 2003, available at <http://www.domovina.net/archive/2003/20031124_ manning.pdf>, accessed 18 March 2009. 
in Prosecutor v Blagojević. ${ }^{78}$ This summary report drew on 50,000 pages of autopsy reports, 30,000 photographic images, and 11,000 physical exhibits, many of which were subject to further expert examination.

Rule 92 bis (D) also specifically authorises the admission of trial transcripts of evidence previously given by a witness during ICTY proceedings, provided the evidence does not relate to the acts and conduct of the accused. This includes the admission of expert evidence. In the Blagojević case, statements and transcript testimony of numerous experts relating to mass grave exhumations and examination of the exhumed bodies to determine sex, age, cause of death, etc. from the Krstic trial were admitted in this way. The Trial Chamber was satisfied that the transcript testimonies submitted under Rule 92 bis (D) along with the expert reports submitted pursuant to Rule 94 bis were relevant, of probative value and together provided 'a complete picture of the expert evidence'. ${ }^{79}$

Questions of admissibility or expert qualification do not entail an exhaustive inquiry into the reliability of scientific evidence. If the evidence put forward were deemed unreliable, it would cease being relevant or admissible. ${ }^{80}$ Similarly, the qualifications of an expert may be a sign of her credibility. However, admission of documentary or other evidence does not mean that the fact-finder will believe it. ${ }^{81}$ Clearly, issues of impartiality, independence and reliability of the expert witness may also require further attention. Boas notes that 'while evidence may be excluded because it is unreliable, it need not be shown to be reliable before it is admitted'. ${ }^{82}$ In fact, evidential reliability (including the reliability of particular scientific methods and techniques) appears to be more fully canvassed as a question of weight, rather than of admissibility. As one interviewee put it, 'reliability is tested by cross-examination'. ${ }^{83}$ Only by admitting the evidence and scrutinising it within the context of the case as a whole can judges properly weigh the evidence as one 'piece of the jigsaw' that 'has to be tied in with other evidence ${ }^{84}$ presented at trial. A contextual approach is especially appropriate in relation to physical evidence recovered from mass graves, which is almost invariably circumstantial and difficult to interpret in isolation.

78 See Blagojević and Jokić, above n. 69 at para. 30.

79 Ibid. at para. 35.

80 R. Gallmetzer, 'Rules of Evidence Applicable at the International Criminal Court', Paper presented at the Marie Curie Top Summer School on International Criminal Law, The Hague, 9 July 2008, para. 35.

81 Delalić et al., above n. 56 at para. 20.

82 G. Boas, 'Creating Laws of Evidence for International Criminal Law: The ICTY and the Principle of Flexibility’ (2001) 12 Criminal Law Forum 59.

83 ICTY judge \# 2, personal interview, 3 October 2007.

84 Ibid. 


\section{Testing 'forensic truth'}

Fairness demands that the opposing party in an adversarial proceeding must be given the opportunity to test the truthfulness of evidence presented to the fact-finder. Trial procedure at the ICTY adopts the familiar common law model of examination-in-chief by the party calling the witness, cross-examination by opposing parties, and, if necessary, re-examination to deal with matters brought out under cross-examination. Judges may ask witnesses questions at any stage.

A court's assessment of scientific reliability is often facilitated by the opposing party employing its own expert, and, if necessary, employing an independent court-expert to further explore matters of scientific method. ${ }^{85}$ In the case of mass grave exhumations and associated mortuary work, however, the reproducibility of findings is problematic, since the original analysis and observation cannot be repeated. Reinvestigations of the same crime scenes and mass graves are to all intents and purposes impossible. Supplementary experts are consequently restricted to providing second opinions on their colleagues' work on the basis of written reports and visual documentation, such as video recordings and photographs. Although this is an attenuated process with obvious limitations, reviews and counter-expertise function as quality control mechanisms, confirming or discrediting an expert's methods, process and knowledge. Ideally, any epistemological gaps or methodological defects will be detected from within the scientific community, facilitated by lawyers' questioning and the procedural structures of the Tribunal, rather than being safeguarded from the outset by judicial rulings on admissibility.

Testing the reliability and credibility of scientific evidence may involve some or all of the following related issues:

1. the expert's qualifications and status as an expert;

2. the scientific methods adopted;

3. norms of practice;

4. acceptance within the scientific community and validation of methods through publications and peer-review;

5. whether and how the science is produced for litigation; and

6. the novelty of the scientific evidence presented. ${ }^{86}$

85 Professor Helena Ranta, for example, was called during the Milošević trial as a court witness to provide information on the Racak incident and the work the European Union Forensic Expert Team conducted in cooperation with Serbian experts (Milošević (Case No. IT-02-54) Trial Chamber Transcript, 12 March 2003.

86 See Edmond, above n. 51 for a detailed description of 'judicial craft skills' used to evaluate scientific evidence. 
According to Schabas, evaluating expert evidence essentially boils down to considering professional competency, methodologies and the credibility of the findings in context. ${ }^{87}$ The expert testimony of forensic anthropologist Dr William Haglund, presented to the ICTY in the Popović trial on 15 March 2007, may serve as a detailed illustration.

\section{Dr Haglund's testimony in Popović}

Dr Haglund's examination-in-chief began in the conventional way, with discussion of his education and qualifications, ${ }^{88}$ employment record and relevant experience. ${ }^{89}$ Attention then turned to the exhumation work that Dr Haglund and his team had conducted at the request of the Office of the Prosecutor. His testimony covered different grave locations, grave properties, numbers of victims found at each site, positions and conditions of their bodies and the causes of death, along with other physical evidence such as blindfolds. ${ }^{90}$ The expert witness report is authenticated by demonstrating its internal logical coherence, external consistency with broader scientific opinion and confirmation through the expert's oral testimony.

There was some pre-existing controversy surrounding Dr Haglund (and one of his colleagues) arising from work during the forensic investigations in question and on a previous occasion. In particular, the anthropological methods employed by Dr Haglund in Rwanda had been criticised by forensic anthropologist and bestselling novelist Dr Kathy Reichs in the Rutaganda case. ${ }^{91}$ In anticipation of defence attacks on Dr Haglund's credibility, the prosecution emphasised that Dr Haglund had been cleared of allegations of misconduct and that a formal inquiry ${ }^{92}$ had concluded that, despite managerial and logistical shortfalls, the scientific validity of Dr Haglund's archaeological work was not compromised. If errors had been made, they had arisen only through the accelerated pace of recovering

87 See Schabas, above n. 1 at 480.

88 Popović et al. (Case No. IT-05-08-T) 'Expert Witness Testimony by Forensic Anthropologist Dr William Haglund' Trial Chamber Transcript, 15 March 2007, at 8900.

89 Ibid. at 8901-8.

90 Ibid. at $8910-12$.

91 Ibid. at 8922-30.

92 In response to the numerous complaints voiced against Dr Haglund throughout the 1996 investigations in the former Yugoslavia, the Office of the Prosecutor set up a panel of forensic experts from the United States to review the allegations. The panel met in San Antonio to hear witness statements alleging misconduct, but cleared Dr Haglund of wrongdoing. Whilst the author was unable to obtain the original report relating to the San Antonio inquiry, the trial transcripts provide information as to its content; this information is compatible with an account of events given by forensic scientist \# 1, telephone interview, 17 March 2008. 
human remains under pressure of time, not from any defect in the scientific methodology itself..$^{93}$

In cross-examination, the opposing party might aim to discredit the expert as a reliable source of knowledge. A cross-examiner could challenge the expert's scientific method or techniques or seek to undermine the expert's particular findings and conclusions. Another strategy is to call counter-expertise in rebuttal. ${ }^{94}$ In Popović, one defence attorney dwelt on the allegations of 'sloppy work' ${ }^{95}$ levelled against Dr Haglund. He pointed out that the Rutaganda judgment from December 1999 had preceded Dr Haglund's testimony in Krstić, yet neither party had on the later occasion mentioned the ICTR's findings against Dr Haglund in its Rutaganda judgment. Dr Haglund was also confronted with a statement that he had made at a seminar in May 2000, in which he referred to the four grave exhumations carried out by him in Bosnia as a 'four-ring circus', ${ }^{96}$ the clear implication being that $\mathrm{Dr}$ Haglund's working practices were chaotic, and by his own admission. In a further attempt to discredit the witness, the defence contrasted Dr Haglund's lack of membership in the American Board of Forensic Anthropology, a professional association, with the elevated professional status of the defence expert, Dr Kathy Reichs. $^{97}$

\section{Professional obligations of the forensic science expert}

The cross-examination of Dr Haglund in Popović demonstrates the intimate relationship between witness credibility and professional conduct and ethics. Willmore suggests that codes of practices that are negotiated between the legal system and scientific disciplines and validated by society provide useful non-case-specific guidelines to adjudicators. ${ }^{98}$ However, no such negotiated code of practice between international law, scientific disciplines and the international community exists. There is neither a standardised agreement regarding forensic

93 See Popović et al. (Case No. IT-05-08-T) 'Expert Witness Testimony by Forensic Anthropologist Dr. William Haglund', above n. 88 at 8921.

94 Schabas argues that '[b]ecause expert testimony consists of the opinion of an individual, it is best answered with counter-expertise, rather than an attempt to deny its validity'. Above n. 1 at 481.

95 See Popović et al. (Case No. IT-05-08-T) 'Expert Witness Testimony by Forensic Anthropologist Dr William Haglund', above n. 88 at 8931.

96 Ibid. at 8971, line 3. See also: W. Haglund, 'From Rwanda to East Timor: Collecting Physical Evidence of War Crimes' (6 May 2000), Paper presented at Conflicts and War Crimes: Challenges for Coverage Seminar, Washington DC, available at <http://www.crimesofwar.org/seminars/ day2-haglund-p3.html>, accessed 18 March 2009.

97 Ibid. at 8980.

98 See Willmore, above n. 7 at 47. 
exhumation practices and principles, nor an overarching ethical code for practitioners on international missions. ${ }^{99}$

In the absence of bespoke normative standards, the legal system implicitly relies on an ethos of scientific professionalism which transcends national and cultural boundaries and binds each forensic practitioner to high standards of competence and integrity in the service of justice. Ultimately, forensic scientists provide data to the justice sector, be that in the furtherance of domestic or international justice.

Generally speaking, the professional standards contained in forensic practitioner codes of ethics fall into the following categories:

(1) obligations to follow the scientific method in performing examinations and formulating conclusions; (2) requirements concerning the impartial interpretation and presentation of laboratory results; (3) behavior concerning courtroom demeanor and delivery of expert testimony; and (4) obligations to the profession as a whole and maintenance of one's own professional skills. ${ }^{100}$

Specifically designed for forensic investigations of war crimes, crimes against humanity and extra-judicial killings, the Inforce Foundation in its overarching ethical principles emphasises the importance to only 'provide confidential, informed and impartial advice' ${ }^{101}$ The statement of good practice further specifies that the experts must 'act with integrity and honesty in all circumstances', ${ }^{102}$ maintain and develop their professional expertise through keeping up-to-date with research and new developments in their field of expertise and inform the

99 A number of, mostly similar, guidelines have been produced by the UN, governments and NGOs: e.g. M. Cox, A. Flavel, I. Hanson, J. Laver and R. Wessling (eds), The Scientific Investigation of Mass Graves: Towards Protocols and Standard Operating Procedures (Cambridge University Press: Cambridge, 2008); National Institute of Justice and US Department of Justice, Mass Fatality Incidents: A Guide for Human Forensic Identification (US Department of Justice Office of Justice Programs: Washington, 2005); Interpol, 'Draft of the New Disaster Victim Identification Guide' (2008), available at <http://www.interpol.int/Public/DisasterVictim/Default.asp>, accessed 18 March 2009; and International Committee of the Red Cross, Missing People, DNA Analysis and Identification of Human Remains. A Guide to Best Practice in Armed Conflicts and Other Situations of Armed Violence (International Committee of the Red Cross: Geneva, 2005).

100 J. L. Peterson and J. E. Murdock, 'Forensic Science Ethics: Developing an Integrated System of Support and Enforcement' (1989) 34 Journal of Forensic Sciences 753.

101 Inforce Foundation, 'Overriding Code of Conduct' (2006), available at <http://www.inforce.org.uk/ page/code_of_conduct_0/>, accessed 20 March 2009.

102 Ibid. 
relevant authorities of situations that might end in malpractice. ${ }^{103}$ The duties of expert witnesses in particular are to provide evidence and assistance only within the parameters of the expert's specific expertise, 'to disclose all findings, irrespective of their implications ${ }^{104}$ and to disclose any limiting and restricting factors that might have adversely affected their findings. ${ }^{105}$

On the downside, codes of practice have limited binding force and can be hard to police and enforce in practice. ${ }^{106}$ As a consequence, scientists may feel that compliance is discretionary, albeit that the prospect of reputational damage could provide strong motivation to comply, especially if effective complaint mechanisms are in place. During the 1997 inquiry into allegations of misconduct by Dr Haglund and pathologist Dr Kirschner, Kirschner was criticised for altering death certificates, whilst Haglund was cleared of allegations of poor judgment, ineffective management, seeking media attention and conducting work of poor quality. ${ }^{107}$ The longer-term implications of such investigations are difficult to assess, although neither of these experts was hired by the Office of the Prosecutor again. There are those who believe that complaints from within the forensic science community are 'almost certainly unrepresentative and under-representative of the actual problems occurring, ${ }^{108}$ suggesting that incompetence and unethical behaviour might be more widespread than is currently acknowledged.

It is the ethical and legal obligation of any expert to provide truthful, impartial and independent assistance to the court. And as one interviewee said: 'there is no need to have ... specific ethical rules for a specific court or tribunal because ... the ethical rules should follow the expert'. ${ }^{109}$ On this view, there is no need for the ICTY's RPE to rehearse obligations that are already implicit in the basic function of the forensic scientist, whose primary duty is 'to bring science to justice'. ${ }^{110}$

103 Ibid.

104 Inforce Foundation, 'Acting as an Expert Witness' (2006), available at <http://www.inforce.org.uk/ page/code_of_conduct_3/>, accessed 20 March 2009.

105 Ibid. See also J. Clark, 'Pathological Investigation' in J. Payne-James (ed.), Encyclopaedia of Forensic and Legal Medicine (Elsevier: London, 2005).

106 See Peterson and Murdock, above n. 100 and Willmore, above n. 7.

107 See Popović et al. (Case No. IT-05-08-T) 'Expert Witness Testimony by Forensic Anthropologist Dr William Haglund', above n. 88 at 8931.

108 M. J. Saks, 'Prevalence and Impact of Ethical Problems in Forensic Science' (1989) 34 Journal of Forensic Sciences 780.

109 ICTY judge \# 1, telephone interview, 27 September 2007.

110 Forensic expert \# 2, personal interview, 3 October 2007. 


\section{Weighing expert evidence}

Zahar and Sluiter observe that '[c]ross-examination, giving evidence under oath, and the direct perception of the witness's demeanour are key factors in attaching weight to live testimony'. ${ }^{111}$ Fact-finders will consider whether an expert witness appears honest, independent and impartial, and must try to establish whether investigative work has been conducted according to appropriate scientific standards. Qualification as a bona fide 'scientific expert' does not necessarily guarantee the quality of the work conducted in any particular case. ${ }^{112}$ As one interviewee mused, '[a]1l witnesses are fallible, whether they deliberately lie or whether they are convinced that they are telling the truth but they got it wrong'. ${ }^{113}$ With this truism in mind, judges need to approach the crucial task of assessing the weight of expert witness testimony with care and circumspection.

We have seen that scientific rigour during mass grave exhumations may be compromised by the novelty of the procedures involved, logistical shortfalls, administrative difficulties and managerial inexperience, as well as by the errors of individual experts. ${ }^{114}$ Judges nonetheless seem to share society's broadly based faith in scientific method, rooted in the assumption that 'following the same scientific approach, the conclusions will be the same' ${ }^{115}$ Science can 'put hard facts to a lot of suppositions'. ${ }^{116}$ It provides powerful corroboration enabling judges to say: 'this [matter] is in fact beyond dispute'. ${ }^{117}$ If proper procedures were followed, only in exceptional circumstances can the results be challenged. ${ }^{118}$ In Krstić, for instance, the ICTY Trial Chamber found that scientific evidence corroborated 'important aspects of the testimony of survivors from the execution sites'119 and was sufficiently credible and compelling to confirm the actus reus of genocide. The judges ruled that most of the c.7,000 people missing following the fall of

111 Above n. 58 at 393.

112 See Faigman et al., above n. 13.

113 International lawyer, personal interview, 24 April 2007. This generic statement was made by an interviewee relating to a separate case study, but is still relevant to the context at hand.

114 Dr Haglund made it clear in his testimony that his report writing was the first of its kind: 'nobody had ever put together a report on multiple remains like this ever before in history': Popović et al. (Case No. IT-05-08-T) 'Expert Witness Testimony by Forensic Anthropologist Dr William Haglund', above n. 88 at 9004 .

115 ICTY judge \# 1, telephone interview, 27 September 2007.

116 Forensic expert \# 3, personal interview, 30 May 2007.

117 ICTY judge \# 2, personal interview, 3 October 2007.

118 Even defence expert Dr Zoran Stanković, whilst challenging evidence of cause of death, 'accepted that the exhumations were conducted by experts with "substantial professional experience and adequate technical, scientific and moral integrity”: Krstić (Case No. IT-98-33) Trial Chamber Judgment, 2 August 2001, para. 76.

119 Ibid. at para. 71. 
Srebrenica had been executed and buried in mass graves. ${ }^{120}$ By demonstrating that the executions had followed a 'well-established pattern'121 requiring premeditation and infrastructure and through establishing the fact that bodies were not only hidden in mass graves, but were later dug up in a further attempt at concealment (in the process commingling and mutilating body parts), forensic science was able to supply vital evidence relating to the perpetrators' criminal intent. ${ }^{122}$

Proceedings at the ICTY have to grapple with a level of complexity unmatched by any national criminal trials. Eyewitnesses, especially those who are victims, often have an emotional or political interest in the conviction or acquittal of the accused, which may sometimes affect the credibility of their testimony. In these circumstances, first-hand, unbiased scientific evidence can be crucial. That said, most of the scientific evidence adduced before the ICTY is directed towards establishing crime scenes. The complexity of such forensic investigations for criminal purposes is immense. According to one interviewee, however, the 'formula' for successful prosecution is 'fairly simple':

the number of bodies, the methods of how they were killed, gathering any forensic evidence that is located in the grave, the timeframe that the crimes were committed and things like that. ${ }^{123}$

This information seldom directly implicates particular accused, and consequently 'isn't that controversial'. ${ }^{124}$ Owing to the ICTY's jurisdictional limits and legal mandate, it is generally the masterminds who planned and ordered genocide and crimes against humanity that stand accused, not the low-level perpetrators who actually carried out the executions at mass grave sites.

In sum, the importance of these forensic investigations rests not so much on finding a single piece of evidence linking individual perpetrators to their victims, but rather in patiently building up a picture of systematic criminality by

120 Ibid. at para. 82 .

121 Ibid. at para. 68 .

122 See Klinkner, above n. 41 at 462 . The view that Krstić's criminal intent had been shown was not shared by the Appeals Chamber: Krstić (Case No. IT-98-33-A) Appeals Chamber Judgment, 19 April 2004, para. 134. However, the Krstić ruling and its use of forensic evidence has since been relevant to other Srebrenica-related cases (e.g. Blagojević, Popović et al. and Milošević) but also the 2007 Genocide case, in which the International Court of Justice (ICJ) referred repeatedly to the Krstić judgments, particularly regarding the definition of a protected group within a geographically limited area and the Srebrenica massacre.

123 ICTY lawyer \# 1, telephone interview, 22 May 2007.

124 ICTY judge \# 2, personal interview, 3 October 2007. 
identifying targeted groups of victims and recovering their remains. Whilst mass grave investigations require the highest levels of concentration, accuracy and methodological expertise, the evidence eventually presented in court typically depicts a much more broad-brush picture of crime scenes and victims. Furthermore, the value of scientific evidence depends on the level of perpetrator in question: the higher up the chain of command, the less detailed crime base evidence is required. ${ }^{125}$

\section{A pragmatic approach towards forensic science expertise}

The ICTY merges civil law and common law procedural traditions in a unique international criminal practice, which has attracted much controversy. A flexible approach towards the admissibility of evidence is routinely justified on the basis that the ICTY operates with professional fact-finders committed to determining objective truth. Critics say that this amalgam creates an 'uncertain, obscure, and unworkable body of law that does not expedite proceedings, but offers numerous possibilities for parties to submit motions for the exclusion of evidence'. ${ }^{126}$ Others contend that judicial liberality results in the admission of dubious evidence which serves only to prolong proceedings and complicate the tasks of adjudication. ${ }^{127}$ What are the implications of this general debate for scientific evidence and expert witness testimony?

Experience in the United States post-Daubert ${ }^{128}$ amply demonstrates the limitations of rules of admissibility for the purposes of assessing scientific validity. Law-and-science scholar Jasanoff explains that by introducing a new threshold for the admissibility of scientific evidence '[i]t became a question of law, to be decided by judges, whether expert evidence is sufficiently scientific to merit consideration in legal fact-finding, ${ }^{129}$ In other words, judges were asked to assess and validate science as scientists would, a gate-keeping role for which judges are not necessarily well suited. Furthermore, the Daubert approach may rest on the kind of positivistic assumptions that were questioned in the first part of this article. This

125 The difference between the number of expert witnesses testifying in Krstić and Milošević is quite striking. In Krstić two forensic anthropologists, two forensic pathologists, one forensic archaeologist and two ICTY investigators gave evidence regarding the Srebrenica massacres. In Milošević, one investigator gave the summary evidence regarding Srebrenica, one forensic pathologist provided the summary findings from forensic investigations in Kosovo, another pathologist gave evidence relating to killings in Croatia and one more court-expert witness was invited to provide evidence regarding the Racak killings.

126 See Zahar and Sluiter, above n. 58 at 394.

127 P. Murphy, 'Excluding Justice or Facilitating Justice? International Criminal Law Would Benefit from Rules of Evidence' (2008) 12 E \& P 1.

128 Daubert v Merrell Dow Pharmaceuticals Inc. 509 US 579 (1993), US Supreme Court.

129 See Jasanoff (2005), above n. 3 at 57. 
naïve view, argues Jasanoff, can result in uncritical reliance on science which may defeat the interests of justice.

For the most part eschewing specialist rules or doctrines, the ICTY has relied on tried-and-tested forensic procedures for the evaluation of scientific evidence. The slender body of rules contained in the ICTY's RPE reflect implicit faith that effective communication between science and the law is possible, notwithstanding disciplinary differences, and that traditional legal procedures will facilitate accurate truth-finding. Questions of scientific methodology and reliability, and of experts' credibility, objectivity and impartiality, are addressed through the process of live testimony in court and tested through cross-examination. Oral testimony provides judges with 'an excellent opportunity to have the expert in the courtroom and put questions' which in turn provides assurance 'in the field of fact-finding'. ${ }^{130}$ Judges may also have the benefit of considering counter-expertise or the testimony of court-appointed experts. Above all, the ICTY's flexible approach to the reception of scientific evidence does not require judges to think like scientists when assessing admissibility. RPE Rules 94 bis and 95 provide for the qualifications of experts and the reliability of their evidence to be considered. While evidence obtained by unreliable methods should be excluded, it does not have to be excluded before being thoroughly examined in court. It is by mutual scrutiny of the forensic scientists themselves, facilitated by legal procedures, that any epistemic or methodological problems or questionable conduct comes to light.

The paucity of specific rules governing the admissibility of expert evidence at the ICTY (or, for that matter, before other international tribunals) in no way detracts from the critical importance such evidence may play in international criminal proceedings. As we have seen, the probative value of scientific evidence is highly contextual and differs significantly from case to case. Scientific evidence from mass grave exhumations tends to provide base crime information not necessarily linking to particular accused, especially if they are high-level perpetrators. It is normally only one strand of proof, which often supplies corroboration for eyewitness testimony or other evidence. The procedural innovation of summary reports has created a time-efficient way to present non-contentious scientific evidence to the Tribunal, whilst still allowing the experts to be called and examined in person where further clarification regarding the sources of the summary report is needed. ${ }^{131}$

130 ICTY judge \# 1, telephone interview, 27 September 2007.

131 See Blagojević and Jokić, above n. 69 at para. 32. 
Despite age-old controversies about the epistemological foundations of science, and forensic science in particular, and the endless debates regarding the law-science interface, confidence in scientific method is not misplaced. As the philosopher Simon Blackburn puts it, '[t]here may be rhetoric about the socially constructed nature of Western science, but wherever it matters, there is no alternative'. ${ }^{132}$ These epistemological debates appear somewhat rarefied for the practical purposes of international criminal litigation. At the ICTY, judges are expected to remain within their own field of expertise by employing a combination of legal rules, ethical values, common sense and logical consistency when weighing the evidence. And in many respects, this position resembles philosophical pragmatism. In Rorty's formulation, the core of pragmatism is 'to replace the notion of true beliefs as representations of "the nature of things" and instead to think of them as successful rules for action'. ${ }^{133}$ This pragmatic position

rejects the positivist belief in an unchanging, objective, universal truth while at the same time rejecting the skeptical or relativist proposition that there is no truth. Pragmatism recognizes the tentative and context-dependent quality of knowledge, but posits that practical action is possible and necessary in the face of this uncertainty. Pragmatism embodies respect for the power of argumentation and persuasion in producing such action. ${ }^{134}$

For judges sitting in international criminal tribunals, the action required is to weigh the evidence presented to them and render justice. The ICTY provides an institutional forum for argument, discussion and persuasion between the parties, assisted by forensic science experts of their choosing. Structured by minimalist, yet adequate, procedural rules regarding expert testimony, these arrangements should suffice, from a pragmatic point of view, to arbitrate between reliable and unreliable, as well as scientifically valid and invalid, evidence.

132 S. Blackburn, Truth: A Guide for the Perplexed (Penguin: London, 2006) 196.

133 R. Rorty, 'Pragmatism without Method' in R. Rorty, Objectivity, Relativism and Truth. Philosophical Papers Vol. I (Cambridge University Press: Cambridge, 1991) 66.

134 E. A. Scallen and W. E. Wiethoff, 'The Ethos of Expert Witnesses: Confusing the Admissibility, Sufficiency and Credibility of Expert Testimony’ (1998) 49 Hastings Law Journal 1148. 
Copyright of International Journal of Evidence \& Proof is the property of Vathek Publishing Ltd and its content may not be copied or emailed to multiple sites or posted to a listserv without the copyright holder's express written permission. However, users may print, download, or email articles for individual use. 